\title{
Attitude of Youths towards News Media Listenership in Southeast Nigeria
}

\author{
Ojiaku, Obinna $\mathrm{C}^{1}$, Nwatu, Chibuike $\mathrm{B}^{2}$, Nwachi, Lilain. $\mathrm{N}^{3}$ \\ ${ }^{1}$ (Department of Marketing, Nnamdi Azikiwe University, Awka, Anambra State) \\ ${ }^{2}$ (Department of Marketing, Enugu State University of Science \& Technology, Enugu) \\ ${ }^{3}$ (Department of Marketing, Federal Polytechnics Uwana, Afikpo, Ebonyi State)
}

\begin{abstract}
This study seeks to investigate youths' attitude towards news media listenership. Specifically, it examines the relationship between youths' attitude (affective, behavioural, and cognitive attitude) towards news on radio and satisfaction with such news quality. It also examines the difference in the interest of young men and women towards news genre. 249 respondents were sampled from Federal Polytechnic Uwana, Afikpo and Nnamdi Azikiwe University, Awka. Correlation results show that the affective, behavioural and cognitive components of attitude correlates positively with young satisfaction with quality of news on radio. Also interest in news differs between young men and women. The implication of the findings is discussed.
\end{abstract}

Keywords: Attitude, Affect, Cognitive, News, Nigeria, Satisfaction,

\section{Introduction}

The changing landscape of news media consumption has brought about an increase in the plurality of media platforms for obtaining news worthy information (Operman, 2014) which has both shaped and defined the current generation of young people (UNICEF, 2004). Typically, such news media platforms are structured into the traditional media of news readership (e.g., newspapers and magazines), viewership (e.g., TV) and listenership (e.g., radio) on the one hand and on digital media (e.g., internet) on the other hand. News stories generally are important to everyone irrespective of their demography or background (Veinberg, 2014). Radio news listenership is the second most important activity for children and young people worldwide after television. (UNICEF, 2004). Generally, radio has a wider reach than most other media due to its relatively cheap nature and the wide availability of radio receivers (Adam \& Harford, 1999). In recent times, the number of radio stations has increased exponentially following the emergence of private radio stations (UNICEF, 2004). For instance there are more than thirty radio stations in the FM wave in southeast Nigeria (Wikipeadia.com).

The news media plays a central role in informing young people and socializing them into larger social world, political systems and cultural values (Lemish \& Alony, 2014). It also socializes youth into public engagement and citizenship. To marketers, young people news media consumption pattern means long-term product participation and the future adult market for most products. This is more so given the increasing rise in competition and the dominance of advertising as the main source of media income (Rozukalne, 2012). Documentary evidence demonstrates the selective exposure by young people to news source. They wish to be informed and involved in the world of news (Lemish \& Alony, 2014) and have indicated relatively high interest in news and current affairs for both local and international discourse (UNICEF, 2004). Howbeit, disparate views exist on the measurement of youth news media listenership (Sternberg, 1995). The youth segment makes up about one third of the world population and more than half of the population of less developed nations (UNICEF, 2004). Paradoxically, evidence exists to suggest a declining rate of news media consumption among young people as well as interest in public affairs (Lemish \& Alony, 2014). Youths are increasing less interested in reading, viewing or listening to news and current affairs more than ever before (Evard, 1996; Sternberg, 1998). They are much more committed to social media participation and the use of the internet generally for communicating and socializing (Veinberg, 2014). These developments generate anxiety over the future of citizenry and democratic participation (Lemish \& Alony, 2014) as well as threatens media solvency and future markets for product participation. Accordingly, youths' attitudes towards news media consumption have become a significant factor in terms of media. Young people are believed to be important consumer group capable of improving revenue for marketers and media practitioners (Rozukalne, 2012). Thus, interest of researchers and policies makers has focused on investigating youths and media consumption in recent times. However, much of the research on young people and news media consumption examined news viewership or readership with few studies isolating news on radio for analysis (Wright \& Hosman, 1986); In addition, attitude towards news media consumption is yet to be investigated with regard to the ABC model of attitude. The purpose of this study is to examine youths' attitude towards news listenership in Southeast Nigeria. Specifically this study will ascertain the difference in interest between young men and women for different news genre and finally ascertain relationship between youths' news listenership and satisfaction with news quality.

DOI: 10.9790/487X-1906067379 www.iosrjournals.org $73 \mid$ Page




\subsection{Research Questions}

Against the background of these developments, the following research questions will guide this study:

a. What is the relationship between youths' attitude towards news media listenership and satisfaction with news quality?

b. Is there any significance difference in interest in news genre between young male and female?

\subsection{Youth and News Media Listenership}

\section{Review Of Related Literature}

In the context of this study we define youths as person between the ages of 15-25 years. Whereas, news is established journalism written by professionals and delivered through the main stream media channels (Operman, 2014). Interest in news stories stem from its importance to everyone irrespective of age, gender, tradition or place of residence (Veinberg, 2014). However, young people media consumption has attracted the interest of researchers and media practitioners. Rozukalne (2012) argued that age group does not necessarily determine media habit but influences from social values, popular lifestyle and traditions which informs young people adaptation of the media as consumers. However, with respect to news media listenership, age has been found to correlate with radio listenership (Nureli, Okoye, Okunna \& Ayo, 1993). Studies have shown young people are good radio audiences particularly to news and current affairs (Nureli et al., 1993; Rozulkane, 2012). In a report by Sternberg (1995) 91 per cent of 15 -24 years old listen to radio in Australia and reducing significantly to 20 per cent in a related study of $10-17$ years between 1990 and 1995 . The situation is about the same for UK and US with 90 per cent and 93 per cent respectively of young people indicating they listen to radio every week and dropping slightly thereafter. In Europe, O' Donnell (2003) report that 63 per cent of young people listen to news on radio everyday in Ireland, Luxemborg and Austria. While for Denmark it is 65 per cent but lower in Italy (21\%), Greece (25\%) and Spain (25\%). In a similar survey, UNICEF (2004) report a high listening rate $(21 \%)$ among young people to political and social events of public international radio broadcasters.

Interest in radio program varies also amongst young people. While researchers reported youths' interest in music and entertainment programs mostly on radio, Finger (1994) cited in Sternberg (1995) argued that news may be an important but underestimated component of youth radio programming. In fact young people nominated radio as the 'source of most news' and the 'best source of news' after Television (Finger, 1994). While in Cupitt et al. (1996) study, 9 per cent of young people gave news as the primary reason for liking radio and majority of young people indicating satisfaction with the quality of news on radio.

\subsection{Attitudes and Attitude Components}

Attitudes are learned predisposition to respond in a consistently favourably or unfavourably way towards a given object. Auzmendi (1992) defined attitude as aspects not directly observable but inferred, comprising of both beliefs as emotions and behavioural predisposition towards a targeted object. Attitude is a psychological tendency expressed by evaluating a particular entity with some degree of favour or disfavour (Eagly \& Chaiken, 1993). According to Hawkins, Coney and Best (2001) attitude is "an enduring organisation of motivational, emotional, perceptual and cognitive process with respect to some aspect of our environment" (p. 394). It consists of the way we think, feel, and act towards some objects. Attitudes are subjective and can only be inferred from the action of others.

\subsubsection{The ABC Model of Attitude}

This study is premised on the affect, behaviour and cognition model of attitude. Basically, these are the pedagogical component of attitude and are the basis for determining attitude (Garcia-Santillan, Moreno-Garcia, Carlos-Castro, Zamudio-Abdala \& Garduno-Trejo, 2012).

\section{Affective component}

Affective component refers to the emotions or feelings elicited by an individual towards an object. It refers to statements of feelings as expressed towards an object. Affective components are evaluative in nature and vary on a continuum from like to dislike. That is, they capture an individual's overall assessment of the attitude object (Schiffman \& Kanuk, 2009). Affective components are easily accessed in attitudinal survey and are more diagnostic of true attitude than the behavioural and conative attitude (Peters \& Slovic, 2007). Peter and Slovic (2007) argue that affective component has the tendency to strongly influence behaviour. They further posit that individuals do not know their true 'attitude' but are rather influenced from cues internal or external to them. Studies have shown correlation high correlation between affective component of attitude and actual behaviour (Miller \& Tesser, 1986). 


\section{Behavioural component}

Behavioral component refers to the tendency to respond in a certain manner towards an object. It is concerned with the likelihood of undertaking specific actions or behaving in a particular way with regard to an object (Schiffman \& Kanuk, 2009). Behavioral component relates to the expressions of behavioral intention or action or the tendency to act in a specific way (Garcia-Santillan et al., 2012). It may often include the actual behavior itself. However, Hawkins et al. (2001) add the situation which a situation occurs modifies the behavioral intentions and is reflected in the actual behavior.

\section{Cognitive Component}

The cognitive component consists of the total configuration of beliefs an individual holds about an attitude object (Hawkins et al., 2001). It represents the knowledge and perceptions that are acquired by a combination of direct experience with the attitude object and the related information from other sources (Schiffman \& Kanuk, 2009). Cognitive responses generate knowledge, awareness, thought, opinion, perception and beliefs in the mind of an individual. Cognitive component has been found to affect object evaluation but not as strong as the affective component (van den Berg, Manstead, van der Pligt \& Wigboldus, 2006).

\subsection{Samples and Procedures}

\section{Research Method}

The design for this study is a survey research design. Data were collected through intervieweradministered questionnaire to a proportionately stratified sample of young people from Federal Polytechnics Uwana and Nnamdi Azikiwe University, Awka. The choice of Federal Polytechnics Uwana, Afikpo and Nnamdi Azikiwe University, Awka was informed due to their rural and urban location respectively. The stratification was prorated based on the student population for each of the schools. The sample for each of the schools was 148 for Federal Polytechnics Uwana, Afikpo and 175 for Nnamdi Azikiwe University, Awka. Thus, a total of 323 respondents were sampled. Respondents were randomly selected across departments and units from both schools. More than 16 per cent of copies of questionnaire were either not returned or invalid. Also, responses from respondents that indicated they never listened to news on radio were invalidated. Thus, a total of 270 responses were used for the analysis.

\subsection{Measurement Development}

The questionnaire was structured into two sections. Section A, included close ended questions on respondents' demography while section B included multiple scale questions ranging from 1 to 5 with 1 having the lowest score and 5 having the highest score. Questionnaire items were generated from existing literature. Scales were developed based on attitude components of cognition, affective, and conative. That is, based on what young people think, feel and do about news media listenership as well as their news media listenership pattern. To measure the construct reliability, estimates were obtained using cronbach alpha. The reliability estimates for attitude constructs were all greater than 0.70 and are as follows: cognitive attitude $(\alpha=0.75)$, conative attitude $(\alpha=0.81)$, and affective attitude $(\alpha=0.82)$. Scale validity for the construct was measured by face validation using senior academics in the Department of marketing and mass communications.

\subsection{Method of analysis}

Data collected were analysed through SPSS version 17. Descriptive statistics and percentages were obtained for respondents demographics. The first hypothesis was analysed using descriptive statistics and chisquare test statistics. The second hypothesis was analysed using cross- tabulation and Pearson chi-square. Finally, the third hypothesis was analysed using Pearson correlation.

\subsection{Respondents' demographics}

\section{Results}

The respondents were mostly between $18-25$ years $(89 \%)(M=1.89, S D=0.312)$. The gender of the respondents is almost halved between both sexes with male 52.5 percent and female respondents 47.5 percent $(M=1.48, S D=0.50)$. More than half of the respondents are in their 400 level in school $(58.2 \%)$ while about 16 per cent of the respondents are in their 100 level $(M=3.09, S D=1.19)$. The majority of the respondents are from household with 3 to 5 persons $(M=2.13, S D=0.72)$. 
Table I: Respondent Demographics

\begin{tabular}{|c|c|c|c|c|c|}
\hline \\
\hline & & Frequency & Valid Percent & Mean & Standard Deviation \\
\hline \multirow[t]{3}{*}{ Age of respondent } & $15-17$ & 27 & 10.8 & & \\
\hline & $18-25$ & 222 & 89.2 & & \\
\hline & Total & 249 & 100.0 & 1.89 & 0.312 \\
\hline \multirow[t]{3}{*}{ Gender of respondent } & Male & 126 & 52.5 & & \\
\hline & Female & 114 & 47.5 & & \\
\hline & Total & 240 & 100.0 & 1.48 & 0.50 \\
\hline \multirow[t]{5}{*}{ Level of study } & 100 & 39 & 16.5 & & \\
\hline & 200 & 39 & 16.5 & & \\
\hline & 300 & 21 & 8.9 & & \\
\hline & 400 & 138 & 58.2 & & \\
\hline & Total & 237 & 100.0 & 3.09 & 1.185 \\
\hline \multirow[t]{4}{*}{ Household Size } & Less than 3 & 48 & 20.5 & & \\
\hline & $3-5$ & 108 & 46.2 & & \\
\hline & 6\& above & 78 & 33.3 & & \\
\hline & Total & 234 & 100.0 & 2.13 & 0.724 \\
\hline
\end{tabular}

Source: Research data

\subsection{Interest in News Genre}

According to RQ2 significance difference was sought between male and female interest in different news genre. Chi-square test was conducted to examine these differences. Statistical difference was found for the entire news genre except for business news. However, our result shows that male respondents rated political news, sport news, current affairs and weather report more importantly than female respondents, while the female respondents rated education news, health news and other news genre (entertainment) more importantly than male respondents. See Table II below.

Table II. Interest in News Genre between Male and Female

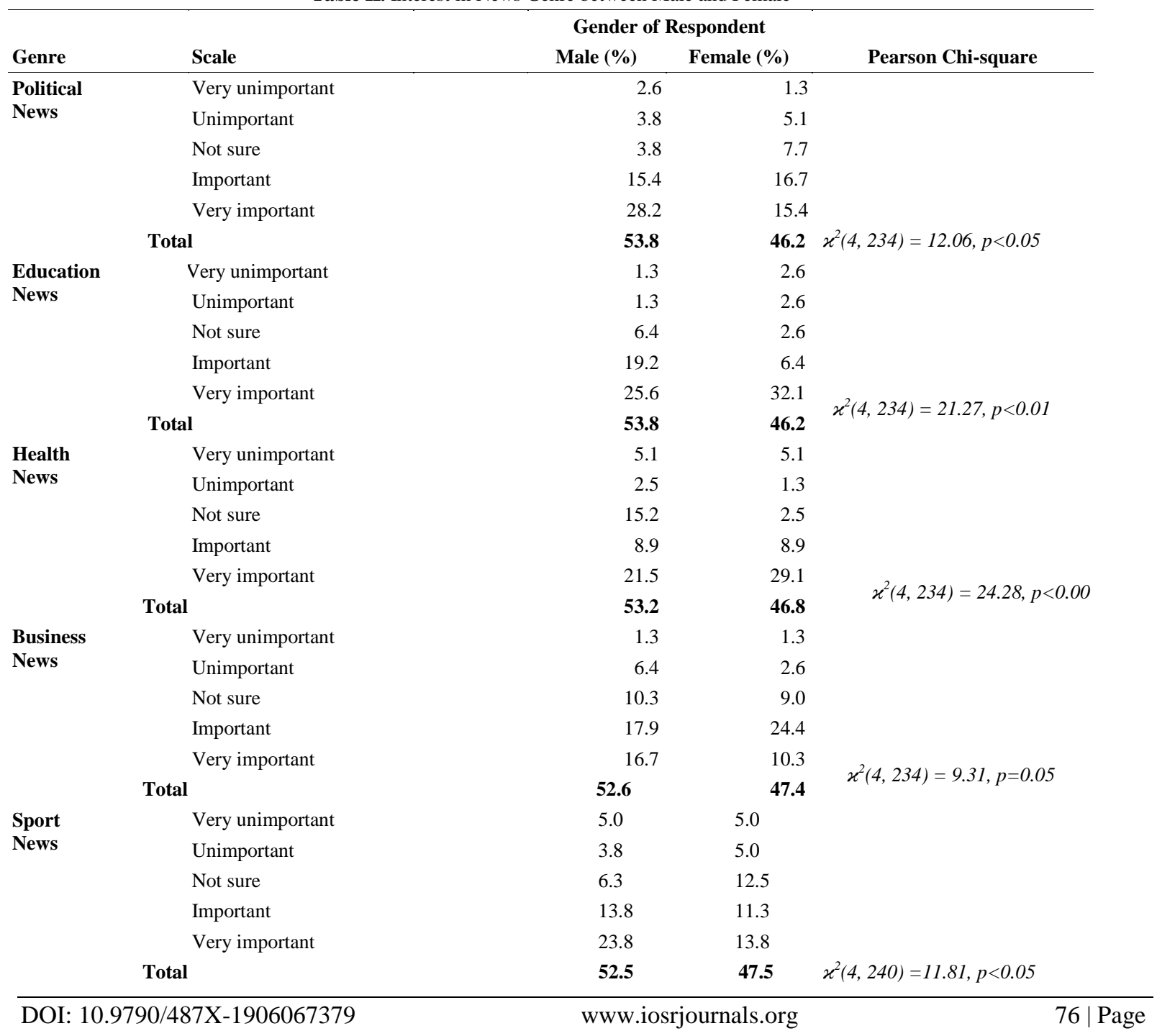




\begin{tabular}{|c|c|c|c|c|}
\hline \multirow{4}{*}{$\begin{array}{l}\text { Current } \\
\text { Affairs }\end{array}$} & Unimportant & 1.3 & 6.5 & \\
\hline & Not sure & 7.8 & 5.2 & \\
\hline & Important & 26.0 & 16.9 & \\
\hline & Very important & 19.5 & 16.9 & \\
\hline \multicolumn{2}{|c|}{ Total } & 54.5 & 45.5 & $x^{2}(4,231)=12.28, p<0.05$ \\
\hline \multirow{5}{*}{$\begin{array}{l}\text { Weather } \\
\text { Report }\end{array}$} & Very unimportant & 10.3 & 2.6 & \\
\hline & Unimportant & 7.7 & 3.8 & \\
\hline & Not sure & 12.8 & 16.7 & \\
\hline & Important & 11.5 & 17.9 & \\
\hline & Very important & 11.5 & 5.1 & \\
\hline \multicolumn{2}{|c|}{ Total } & $\mathbf{5 3 . 8}$ & 46.2 & $\varkappa^{2}(4,234)=22.75, p<0.01$ \\
\hline \multirow[t]{6}{*}{ Others } & Very unimportant & 12.7 & 9.1 & \\
\hline & Unimportant & 10.9 & 3.6 & \\
\hline & Not sure & 12.7 & 16.4 & \\
\hline & Important & 5.5 & 10.9 & \\
\hline & Very important & 5.5 & 12.7 & \\
\hline & Total & 47.3 & $\mathbf{5 2 . 7}$ & $\varkappa^{2}(4,234)=15.10, p<0.01$ \\
\hline
\end{tabular}

\section{Source: Research data}

\subsection{Relationship between news attitude and satisfaction with quality of news}

RQ3 sought to investigate the relationship between youth news attitude and their satisfaction with the quality of news on radio. Respondents were asked to evaluate news on radio based on a number of items categorized as cognitive attitude, conative attitude and affective attitude. Pearson correlation was used to analyze the relationship. The result shows a positive but weak relationship for cognitive attitude $\left(r^{2}=.18\right.$, $\mathrm{p}<0.01)$, conative attitude $\left(\mathrm{r}^{2}=.32, \mathrm{p}<0.01\right)$ and satisfaction. While a positive and moderate relationship was found for affective attitude $\left(\mathrm{r}^{2}=.59, \mathrm{p}<0.01\right)$ and satisfaction.

\begin{tabular}{|c|c|c|c|c|}
\hline & Cognitive attitude & Conative attitude & Affective attitude & Satisfaction \\
\hline Cognitive attitude & 1 & .071 & $.171^{* *}$ & $.176^{* *}$ \\
\hline Affective attitude & & & 1 & $.590^{* *}$ \\
\hline Satisfaction & & & & 1 \\
\hline
\end{tabular}

**. Correlation is significant at the 0.01 level (2-tailed).

\section{Discussions}

This paper investigates youth attitude towards news media listenership. The paper contributes to scholarly discussions on youth consumption of news media by examining their attitude based on the tricomponent model of conative, cognitive and affective attitude and how such attitude relate to satisfaction with news quality. Also, it isolates news on radio for analysis as proposed by Hosman (1986). The study shows how young people access news on radio in this age of media fragmentation and how interest in news genre differs between young men and women. The result shows that youths generally have a positive attitude towards news media listenership and such attitude correlates positively with satisfaction with news quality. This findings partially supports Lemish and Alony (2014) and Cuppit et al. (1996) studies. The relationship between cognitive attitude with items such as 'news on radio is the best source', 'news on radio is the most source of news' and news on radio is the best source of latest news' shows a weak relationship with satisfaction partially confirming Finger (1994) study that found radio nominated in these categories second after television in Australia but contradicts more recent study by Veinberg (2014). The positive and weak relationship found for conative attitude and satisfaction supports earlier studies by (Achte, 2013). Following the pattern of news consumption on radio, young people are likely to tune to news on their own only occasionally irrespective of whether it is at home, in a car or on their mobile device. Young people still tune to radio to stay informed. More importantly, positive and moderately strong relationship was found for affective attitude and satisfaction supporting earlier findings by Cupitt et al. (1996). In other words, young people are favourable disposed to listening to news on radio, feel they learn a lot through radio and above all feel radio news are credible. Furthermore, significant difference was found for interest in news genre between young men and women. Young men dominated in interest in 'male-appropriate' areas such as political news, sports and current affairs, while young women dominated in 'female-appropriate' areas (Lemish \& Alony, 2014: 193) such as health news, education and entertainment news consistent with the findings of Lemish and Alony (2014). However, no difference was reported in their interest for business news. 


\section{Conclusions And Implications}

This study sought to examine young peoples' attitude towards news media listenership. Specifically, youth attitude was examined in relation to their satisfaction with news quality. In conclusion, youths generally have a positive attitude towards news media listenership. More specifically, their cognitive attitude and their conative attitude are relatively weak in relation to satisfaction with news quality. This finding is not entirely surprising given the rise of digital media and the increasing influence of the internet and social media on young peoples' media consumption (Veinberg, 2014). However, our evidence suggests young people show stronger positive affect towards news. The implication is that inspite of the fragmentation on news media; interest on radio listenership has not died. Infact, young people feels news on radio is credible and they are still favourably disposed to news on radio. The implication is that marketers may have to still allocate their promotional budget for radio airtime and not neglecting the media entirely for the digital media. Finally, news consumption by young men and women indicate divergent interest in specific topics construed along male or female appropriate domain. Thus, these differences in news consumption enables young people socialize into specific gender roles. The implication is that advertisers ought to schedule their campaigns during specific news segment with respect to whether they are targeting male or female consumers. However, for product that are gender indifferent the business news segment may be an important period to run such campaigns. In addition, the finding holds some implications for young people civic engagement and political participation.

\section{Limitations And Future Research Direction}

A major limitation of this study is the focus on radio news listenership. Given the growth of more selective, distributive media (i.e. internet) news listenership can be patterned along modern satellite radios or internet radio. Future studies might consider the effect of these media. Though, the study set out to capture the attitude of young people, especially between the ages of $15-30$ years. We may not have adequately captured young people in their mid and late teenage years due to the tertiary institution settings the study was conducted. Future studies may consider including young people in senior secondary schools.

\section{References}

[1] Achte, A (2013). New tricks for old pony: Is it essential for speech radio programs to utilize social media in order to stay relevant to the audience? Reuters Institute Fellowship Paper, Reuters Institute for the study of Journalism, University of Oxford.

[2] Adam, G \& Harford, N. (1999). Radio and HIV/AIDS: Making a difference, a guide for radio practitioners, health workers and donors. Media Action International

[3] ANOP Market Research (1985), Young Australians Today.

[4] Cuppitt, M., Gillian R., \& Sheldon, L. (1996). Music, New Music and All That: Teenage Radio in the 90s, Monograph 5, Sydney, Australian Broadcasting Authority.

[5] Eagly, A.H. \& Chaiken, S., 1993. The psychology of attitudes, Fort Worth, TX: Harcourt Brace Jovanovich.

[6] Evard, M. (1996). What is 'news'?: Children's conceptions and uses of news, HREF http://mevard.www.media.mit.edu/

[7] Finger, J. (1994). Brisbane's Young Adult Radio Audience: Perceptions of News. Unpublished B.A. Honours Thesis, University of Queensland Department of Journalism.

[8] Garcia-Santillan, A., Moreno-Garcia, E., Carlos-Castro, J., Zamudio-Abdala, J.H., \& Garduno-Trejo, J. (2012). Cognitive, affective and behavioral components that explain attitude toward statistics. Journal of Mathematics Research, 4(5), 8-16, doi:10.5539/jmr.v4n5p8

[9] Hawkins, D.I., Best, R.J., \& Coney, K.A. (2001) Consumer Behaviour: Building Marketing Strategy $8^{\text {th }}$ ed. McGraw-Hill. New York. NY

[10] Lemish, D., \& Alony, R.P. (2014). The gendered nature of news consumption by children and youth. Participations: Journal of Audience \& Reception Studies, 11(1), 174-198.

[11] Millar, M.G., \& Tesser, A. (1986). Effects of affective and cognitive focus on the attitude-behaviour relation. Journal of Personality and Social Psychology Bulletin, 16, 405-418.

[12] Nwuneli, O., Okoye, I., Okunna, C., \& Ayo, J. (1993). Media Use, Knowledge of World Affairs and Image of Nations Among Nigerian Youth. Africa Media Review, 7 (1), 33-50.

[13] O'Donnell, S (2003). News Consumption in Ireland and the European Union: Traditional Media vs. the Internet. Irish Communications Review, 9.

[14] Operman, S. (2014). Generational use of news media in Estonia: media access, spatial orientations and discursive characteristics of the news media. Sodertorn Doctoral Dissertations 96. Sodertorns University.

[15] Peters, E., \& Slovic, P. (2007). Affective asynchrony and the measurement of affective attitude component. Cognition \& Emotion, 21(2), 300-329, doi:10.1080/02699930600911440.

[16] Rozukalne, A. (2012). Young people as media audience: from content to usage processes. Central European Journal of Communication, 1, 105-120.

[17] Schiffman, L.G., \& Kanuk, L.L. (2009). Consumer Behaviour. $9^{\text {th }}$ ed. Pearson Education. New Jersey.

[18] Sternberg, J. (1998). Rating youth: a statistical review of young Australians' news media use. Australian Studies in Journalism 7, 84-136

[19] UNICEF (2004). Children, youth and media around the world: An overview of trends and issues. $4^{\text {th }}$ world summit on media for children and adolescents, Rio de Janeiro, Brazil.

[20] van de Berg, H., Manstead, A.S.R., van der Pligt, J., \& Wigboldus, D.H.J. (2006). The impact of affective and cognitive focus on attitude formation. Journal of Experimental Social Psychology, 42, 373-379, doi:10.1016/j.jesp.2005.04.009.

[21] Veinberg, S. (2014). Digital native's attitude towards news sources. Public Relations Review (In press version) available at http://www.sciencedirect.com/science/article/piii/s0363811114001647

[22] Wright, J.W., \& Hosman, L.A. (1986). Listener perceptions of radio news. Journalism Quarterly, 63(4), 802-808, 814. 
[1] This heading is not assigned a number.

\section{References}

[2] A reference list MUST be included using the following information as a guide. Only cited text references are included. Each reference is referred to in the text by a number enclosed in a square bracket (i.e., [3]). References must be numbered and ordered according to where they are first mentioned in the paper, NOT alphabetically.

Examples follow:

Journal Papers:

[3] M Ozaki, Y. Adachi, Y. Iwahori, and N. Ishii, Application of fuzzy theory to writer recognition of Chinese characters, International Journal of Modelling and Simulation, 18(2), 1998, 112-116.

[4] Note that the journal title, volume number and issue number are set in italics.

Books:

[5] R.E. Moore, Interval analysis (Englewood Cliffs, NJ: Prentice-Hall, 1966).

[6] Note that the title of the book is in lower case letters and italicized. There is no comma following the title. Place of publication and publisher are given.

Chapters in Books:

[7] P.O. Bishop, Neurophysiology of binocular vision, in J.Houseman (Ed.), Handbook of physiology, 4 (New York: Springer-Verlag, 1970) 342-366.

[8] Note that the place of publication, publisher, and year of publication are enclosed in brackets. Editor of book is listed before book title.

Theses:

[9] D.S. Chan, Theory and implementation of multidimensional discrete systems for signal processing, doctoral diss., Massachusetts Institute of Technology, Cambridge, MA, 1978.

[10] Note that thesis title is set in italics and the university that granted the degree is listed along with location information Proceedings Papers:

[11] W.J. Book, Modelling design and control of flexible manipulator arms: A tutorial review, Proc. 29th IEEE Conf. on Decision and Control, San Francisco, CA, 1990, 500-506 